\title{
Surface Deterioration of Indirect Restorative Materials
}

\author{
Amanda Mahammad Mushashe ${ }^{1} \mathbb{\oplus}$, Isabelli Carolini Farias ${ }^{1} @{ }^{\circ}$, Carla Castiglia

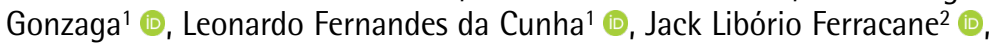 \\ Gisele Maria Correr ${ }^{1}$ (1)
}

\begin{abstract}
The objective of this work was to evaluate the effects of in vitro and in situ biodegradation on the surface characteristics of two resin cements and a hybrid ceramic system. One hundred and eighty specimens $(4 X 1.5 \mathrm{~mm})$ of each material (Maxcem Elite, NX3 Nexus and Vita Enamic) were made and randomly distributed in twelve groups $(n=15)$ according to the material and biodegradation method. The specimens were then submitted to the following challenges: storage in distilled water $37^{\circ} \mathrm{C}$ for $24 \mathrm{~h}$ or 7 days, storage for 7 days, at $37{ }^{\circ} \mathrm{C}$, in stimulated saliva or in situ. The in situ stage corresponded to the preparation of 15 intraoral palatal devices, used for 7 days. Each device presented 3 niches, where a sample of each materials was accommodated. Specimens from both saliva and in situ groups suffered a cariogenic challenge, corresponding to the application of a solution of $20 \%$ of sucrose, 10 times throughout each day. After each biodegradation method, the surface roughness $(R a)$, Vickers hardness (VHN) and scanning electron microscopy (SEM) analyzes were performed. The data collected were evaluated by Levene test, two-way ANOVA and Tukey's test $(\alpha=5 \%)$. The in situ challenge promoted the greater biodegradation, regardless of the material. Regarding the materials, the Vita Enamic VHN was negatively affected by all biodegradation methods and the Nexus NX3 presented better performance than the self-adhesive cement tested. Therefore, within the conditions of this work, it was concluded that in situ biodegradation can affect negatively the surface characteristics of indirect restorative materials.
\end{abstract}

'School of Health Sciences, UP - Universidade Positivo, Curitiba, PR, Brazil

${ }^{2}$ Department of Restorative Dentistry, School of Dentistry, Oregon Health \& Science University, Portland, OR, USA

Correspondence: Amanda Mahammad Mushashe, Rua Professor Pedro Viriato Parigot de Souza 5300, 81280-330 Curitiba, PR, Brasil. Tel: +55-41-3317-3094. e-mail: amandamushashe@hotmail.com

Key Words: biofilm, surface properties, dental materials.

\section{Introduction}

The longevity of indirect restorative procedures depends on numerous factors, many of them related to the physical-mechanical properties of the materials involved and their relationships with adjacent biological and physiological structures. In addition to mechanical and thermal stress, indirect restorative materials, as well as luting agents, are subjected to deleterious chemical action from components of the diet, salivary enzymes and mainly bacterial products. This biodegradation process promotes a gradual disaggregation of the material, potentially leading in the long term to failures in clinical performance (1).

Some in vitro studies (2-4) have proposed to determine the biodegradation of restorative and prosthetic materials, however the characteristic limitation of this study model can lead to inconclusive data regarding clinical performance. Considering that the oral environment presents a large and complex network of variables, it is likely that in situ studies more closely simulate the clinical conditions (5). Through this type of methodological design, it is possible to test variables such as salivary properties (salivary flow, buffer capacity, protein content, etc.), biofilm accumulation (species diversity, competition and succession among microorganisms, etc.), and temperature and $\mathrm{pH}$ fluctuation among other challenges.
Regardless of the method design, biodegradation studies must assess the effect of this process on key physical-mechanical properties of materials, such as: superficial hardness $(1,6,7)$ hybrid layer stability, superficial roughness (8) and others. Clinically, these properties are directly related to factors that may affect the success of indirect procedures such as: collapse of the cervical sealing, progression of secondary caries at the dentin-restoration interface (9), bacterial accumulation and inflammation of the adjacent gingival tissue and decrease of the dentin-cement-restoration complex bond strength (10). Considering the intimate relationship between the ceramic system and the resin cement at the adhesive interface, and the importance of the stability of these materials to the longevity of restorations, the investigation of the effects of biodegradation on the properties of these materials is considered to be very important.

Studies have determined that chemical composition and surface characteristics of materials are directly related to the way they interact with the oral environment $(11,12)$. Dental ceramics, due to their high surface smoothness and characteristic inert chemical structure, tend to promote a thinner biofilm (1-6 $\mu \mathrm{m})$ than those derived from resin composites (13). On the other hand, resin-based materials, besides presenting a greater surface roughness 
that favors bacterial adhesion, are more susceptible to biodegradation, leaching products that can interfere with the microbiological community (14). Cariogenic microorganisms, such as Streptococcus mutans and sobrinus, have proven to have more affinity for resin-based materials than dental tissues or other materials, such as glass ionomer, metals and ceramics (15).

Recently Vita Zahnfabrik introduced Vita Enamic, a new hybrid ceramic system for CAD-CAM restorations, which contains 86 vol\% of feldspathic ceramic and 14 vol\% of polymer network (16). According to the manufacturer, the addition of a resin matrix to the ceramic composition causes a decrease in the elastic modulus of the material, favoring a greater mechanical compatibility with the dentin tissue (16). However, in view of the susceptibility of the polymeric materials to bacterial activity, the resistance to biodegradation of this hybrid ceramic may create some concerns that would not be present for an all-ceramic system. According to the authors' knowledge, no in situ study has evaluated such effects to date.

Therefore, the objective of this work was to evaluate the effects of in vitro and in situ biodegradation on the surface characteristics of two resin cements and a hybrid ceramic system. The hypotheses of this work were: 1) the in situ biodegradation would have greater influence on the surface characteristics of the samples than the in vitro test, and 2) the cements would be more affected than the hybrid ceramic.

\section{Material and Methods}

In order to evaluate the surface degradation of indirect restorative materials, specimens of two resin cement (Maxcem Elite and NX3 Nexus) and a hybrid ceramic system (Vita Enamic) (Table 1) were submitted to in vitro and in situ challenges and assessed by surface roughness $(R a)$, Vickers hardness (VHN) and scanning electron microscopy (SEM), as follows.

\section{Specimen Preparation}

Sixty square-shaped specimens $(4 \times 4 \times 1.5 \mathrm{~mm}$ thickness) of each material tested were produced in standardized conditions $\left(23 \pm 1{ }^{\circ} \mathrm{C}\right.$ and $50 \pm 5 \%$ ).

Vita Enamic blocks were cut into the dimension by aid of a low speed, water-cooled diamond saw (Isomet 1000, Buehler, Germany) while the cement samples were made using a polyvinylsiloxane matrix. The molds were filled with the cements, covered with an acetate strip and pressed with a glass slide to compact the material. The specimens were light-cured for $40 \mathrm{~s}$ by means of a previously calibrated light source at $1000 \mathrm{~mW} / \mathrm{cm}^{2}$ (LED curing light, Skysea Business Co. Ltd., Beijing, China). Samples were then polished by means of a \#600 grit silicon carbide for $15 \mathrm{~s}$ for standardization purpose and sonicated in water for $10 \mathrm{~min}$.

The samples of each material [Maxcem Elite $(\mathrm{mc})$; NX3 Nexus (nx) and Vita Enamic (ve)] were randomly distributed into four groups $(n=15)$, according to the biodegradation method [Control (C); Water (W); Saliva (S) and In Situ (I)].

Biodegradation methods

Specimens of the control and water groups were stored in distilled water at $37^{\circ} \mathrm{C}$ for $24 \mathrm{~h}$ or 7 days, respectively. For the stimulated saliva and in situ groups, 15 volunteers, between 18-25 years, were selected. The inclusion criteria corresponded to the presence of good oral and systemic health and no use of orthodontic appliances, dental prostheses nor medications that could alter oral bacterial flora and/or salivary flow. The study design was approved by the local Ethics Committee.

Samples of S groups (Smc, Snx and Sve) were stored in total saliva collected from the volunteers. The saliva was stored in fifteen containers with the identification of each donor. Each recipient randomly received one sample from each group. Bacterial growth was facilitated by applying a drop of 20\% sucrose into the storage solution, 10x a day, at the following times: $8 \mathrm{~h}, 9 \mathrm{~h} 30,11 \mathrm{~h}, 12 \mathrm{~h} 30,14 \mathrm{~h}, 15 \mathrm{~h} 30$, $17 \mathrm{~h}, 18 \mathrm{~h} 30,20 \mathrm{~h}$, and $21 \mathrm{~h} 30$. The specimens were stored at $37^{\circ} \mathrm{C}$ for 7 days, and the saliva was renewed every two days, through a new collect.

The in-situ design was based on a similar study (13). For the samples of I groups (Imc, Inx and Ive), the same fifteen volunteers of the $\mathrm{S}$ group were submitted to an alginate impression of the upper arch (Hydrogum, Zhermack, RO, Italy) and type III gypsum models were poured. An intraoral

Table 1. Materials tested information

\begin{tabular}{lcccc}
\hline Material & Code & Main Composition & Lot No. & Manufacturer \\
\hline Maxcem Elite & MC & $\begin{array}{c}\text { Glycerol dimethacrylate dihydrogen phosphate, } \\
\text { multifunctional methacrylate monomers, } 67 \mathrm{wt} \% \text { fillers } \\
(2-4 \mu \mathrm{m} \text { average particle size })\end{array}$ & 3262105 & Kerr Corp, Orange, CA, USA \\
Nexus NX3 & NX & $\begin{array}{c}\text { Bisphenol A glycidyl methacrylate, triethylene glycoldimethacrylate, } \\
67.5 \mathrm{wt} \% \text { fillers }(0.6 \mu \mathrm{m} \text { average particle size })\end{array}$ & 6563803 & Kerr Corp, Orange, CA, USA \\
Vita Enamic & VE & $\begin{array}{c}\text { Ceramic phase of } \mathrm{Al}_{2} \mathrm{O}_{3}, \text { urethane dimethacrylate, } \\
\text { triethylene glycoldimethacrylate, }\end{array}$ & 44480 & Vita Zahnfabrik, BS, Germany \\
\hline
\end{tabular}


palatal acrylic device was made for each individual, having 3 niches, one for each material tested.

A plastic mesh was fixed above the niche, leaving a space of $1 \mathrm{~mm}$ for biofilm accumulation on the surface of the samples. Prior to receiving the device, volunteers received written and oral instructions. There was no restriction on the volunteer's diet. The only recommendation was to remove the device during meals and before ingesting any drink or food, leaving the device in a humid environment, in appropriate boxes provided by the researchers. The volunteers were instructed to perform oral hygiene three times a day with a fluoride dentifrice ( $1100 \mathrm{mgF} / \mathrm{g} \mathrm{NaF}$ ), but only the external palatal region of the device was brushed to avoid disturbing the biofilm. The cariogenic challenge was induced as previously described for the saliva groups. Volunteers removed the devices, removed the excess with gauze and a drop of sucrose solution was applied on top of each specimen. The solution was gently dried after 5 min and the device reinserted into the mouth. The period of use of the device was 7 days.

After each biodegradation method, samples were carefully removed from the storage solution and the palatal device and ultrasonically cleaned for $5 \mathrm{~min}$. After the biodegradation methods, the surface characteristics were assessed as follow.

\section{Surface Roughness}

After the cleaning procedures, all specimens were coupled to a roughness measuring device (TR200, TIME Group, Pittsburgh, PA, USA). In order to avoid interfering with the hardness results, the specimens were divided in half, the left side being used for roughness analysis and the right for hardness. To register the Ra, the stylus was moved at a constant speed of $0.5 \mathrm{~mm} / \mathrm{s}$ with a load of 0.7 $\mathrm{mN}$. $R a$ values for each sample were measured along the diameter, with a standard length of $0.25 \mathrm{~mm}$. The average surface roughness $(\mu \mathrm{m})$ of the specimens was obtained through three consecutive measurements, from the center of the disk in different directions $\left(45^{\circ}\right)$.

\section{Surface Hardness}

The microhardness tests were performed using a Vickers indenter device (MHT-230, Leco Corp., St Joseph, USA) and a load of $200 \mathrm{~g}$ for resin cements and $500 \mathrm{~g}$ for the ceramic system, both for $15 \mathrm{~s}$. Three measurements were obtained from each specimen, and the mean VHN was calculated $\left(\mathrm{kg} / \mathrm{mm}^{2}\right)$.

\section{Scanning Electron Microscopy}

Additional representative specimens from each group were ultrasonically cleaned for $5 \mathrm{~min}$ and gently wiped with tissues (Kimwipes, Kimberly-Clark, Dallas, TX, USA) to remove the biofilm. After, all specimens were mounted on a metallic stub, coated and observed under scanning electron microscopy (SEM), at 1000× to observe the surface characteristics.

\section{Statistical Analysis}

The roughness and hardness tests were initially submitted to the Levene test in order to verify the homogeneity of variance. Data regarding the resin cements were then submitted to a two-way ANOVA, with the factors being materials and biodegradation methods. One-way ANOVA was performed for the hybrid ceramic material data, comparing the biodegradation methods. Statistical difference was evaluated by Tukey test (variance homogeneity confirmed), with an overall significance level of 5\%. Statistical tests were performed using SPSS software version 19.0.0.

\section{Results}

\section{Surface Roughness}

The mean and standard deviation values for surface roughness $(R a)$ in the different groups are presented in Table 2. Statistical analysis determined that there was a significant difference between materials $(p<0.01)$, methods of biodegradation $(p<0.01)$ and in the material interaction * biodegradation method $(p<0.01)$.

The $R a$ of the Maxcem Elite cement was significantly higher than the other materials, regardless of the biodegradation method ( $\mathrm{MC}>\mathrm{NX}=\mathrm{VE})$. For the variable biodegradation method, there was a significant difference only for the in-situ group, where $R a$ was in the following order: In situ > control=water=saliva.

\section{Surface Hardness}

The mean and standard deviation values for surface hardness (VHN) in the different groups are presented in Table 3. Statistical analysis determined that there was a significant difference between materials $(p<0.01)$, methods of biodegradation $(p<0.01)$ and in the material interaction *biodegradation method $(p<0.01)$.

There was a significant difference in the VHN between the materials, regardless of the biodegradation method, as follow: $\mathrm{VE}>\mathrm{MC}>\mathrm{NX}$. For the variable biodegradation method, there was a significant difference between the groups, and the VHN was in the following order: Control $=$ Water $>$ Saliva $>$ In situ.

\section{SEM Analysis}

The SEM images showed that the Maxcem Elite material had the highest amount of surface irregularity, defined as voids, gaps and filler exposure, regardless of the biodegradation method. There was an exposure of the filler 
particles for the Wmc and Smc groups, and the presence of a biofilm established in the Ime group (Fig. 1). For the Nexus NX3 and Vita Enamic materials (Fig. 2 and 3), relatively less difference was observed between the biodegradation methods as the samples showed little superficial change.

\section{Discussion}

This work aimed to evaluate the effect of in vitro and in situ biodegradation on surface characteristics of two resin cements and a hybrid ceramic system. The results showed that, independent of the material, the in situ biodegradation method was the one that caused the greatest change in surface characteristic, validating the first hypothesis. Regarding the materials tested, both cements and hybrid ceramic presented some surface deterioration when submitted to different biodegradation methods, rejecting the second hypothesis.

Though laboratory tests have great value, especially in the development and analysis of new dental materials, in vitro studies provide limited similarities to the oral environment. To evaluate the interaction between dental materials and biofilms, in vitro studies are limited in terms of being able to reproduce the many variables affecting the oral environment, such as microbiological diversity, salivary flow variations, oral hygiene, diet, $\mathrm{pH}$, temperature, etc $(1,5)$. Therefore, due to the greater number of chemical, physical and biological challenges to which the samples

Table 2. Mean and standard deviation (SD) values of surface roughness $(R a)$ in the different groups $(\mathrm{n}=15)$

\begin{tabular}{lcccc}
\hline \multirow{2}{*}{ Material } & \multicolumn{4}{c}{ Biodegradation method } \\
\cline { 2 - 5 } & Control & Water & Saliva & In situ \\
\hline Vita Enamic & $0.11( \pm 0,03)^{\mathrm{de}}$ & $0.10( \pm 0,02)^{\mathrm{e}}$ & $0.09( \pm 0,01)^{\mathrm{e}}$ & $0.25( \pm 0,14)^{\mathrm{bcde}}$ \\
Maxcem Elite & $0.26( \pm 0,06)^{\mathrm{bcd}}$ & $0.30(0,11)^{\mathrm{b}}$ & $0.24( \pm 0,04)^{\mathrm{bcde}}$ & $0.70( \pm 0,46)^{\mathrm{a}}$ \\
Nexus NX3 & $0.13( \pm 0,08)^{\text {cde }}$ & $0.13( \pm 0,08)^{\text {cde }}$ & $0.13( \pm 0,05)^{\text {cde }}$ & $0.28( \pm 0,13)^{\mathrm{bc}}$ \\
\hline
\end{tabular}

Mean values follow by different superscript letters indicate statistically significant difference $(\mathrm{p}<0.05)$. Power of 0.75 .

Table 3. Mean (VHN) and standard deviation (SD) values for hardness in the different groups $(\mathrm{n}=15)$

\begin{tabular}{|c|c|c|c|c|}
\hline \multirow{2}{*}{ Material } & \multicolumn{4}{|c|}{ Biodegradation method } \\
\hline & Control & Water & Saliva & In situ \\
\hline Vita Enamic & $321.9( \pm 39,1) \mathrm{a}$ & $329.6( \pm 30,7) a$ & $234.9( \pm 18,6) b$ & $160.2( \pm 39,5) \mathrm{c}$ \\
\hline Maxcem Elite & $68.3( \pm 9,5) d$ & $46.5( \pm 6,7)$ de & $44( \pm 6,0) \mathrm{e}$ & $43.3( \pm 6,6)$ de \\
\hline Nexus NX3 & $40.9( \pm 9,5) e$ & $40.7( \pm 4,4) \mathrm{e}$ & $37.8( \pm 2,3) \mathrm{e}$ & $32.7( \pm 5,1) \mathrm{e}$ \\
\hline
\end{tabular}

Mean values follow by different superscript letters indicate statistically significant difference $(\mathrm{p}<0.05)$. Power of 0.85 . are subjected during an in situ test, the biodegradation produced in this study model was expected to produce more dramatic effects. Results obtained in this study showed that the in situ biodegradation promoted major deterioration in the surface roughness and VHN of materials in comparison to immersion in water for $24 \mathrm{hrs}$ and 7 days. The further biodegradation of restorative materials promoted by in situ methods was also shown by similar studies $(1,13)$. In the other hand, Sen et al. (4) observed that immersion in food-stimulating liquids did not have influence in the VHN of Vita Enamic, also tested in this study. This result corroborates to the fact that in vitro biodegradation method can affect materials properties differently than in situ methods, presenting limited outcomes.

Different storage solutions for materials biodegradation have been described in the literature, such as sodium hypochlorite, ethanol, water, artificial saliva, lactic-acid models, among others $(4,10,17)$. The choice for stimulated saliva in this study was to attempt to better simulate the clinical environment and to allow a more accurate comparison with the data obtained by the in situ test, since the saliva would be donated by the same volunteers participating in both stages of the study. The synergistic effect of the salivary enzymes and the multi-species bacteria was able to promote biodegradation of the samples, determined by the decrease of VHN and by the filler exposure and superficial voids observed on the SEM images (Figs. 1-3). Therefore, one may assume that stimulated saliva is a useful and reliable biodegradation solution.

It is well stated by the literature that the chemical composition and surface characteristics of materials are related to the way they interact with the oral environment and consequently, how they biodegrade $(11,12)$. Considering the inert characteristic of ceramic materials and the inherent susceptibility of resin-based materials in aqueous surroundings, it was expected that the resin cements would more affected by the biodegradation than the VE. However, both cements and hybrid ceramic presented surface changes, rejecting the second hypothesis.

Vita Enamic used in this study, is a hybrid system whose composition refers to a two-phase ceramic network, based a major leucite-based phase of feldspar origin and a minor crystalline phase of zirconia, permeated by a polymethylmethacrylate polymer network $(12,16,18)$. The hybrid ceramic systems were introduced in the 

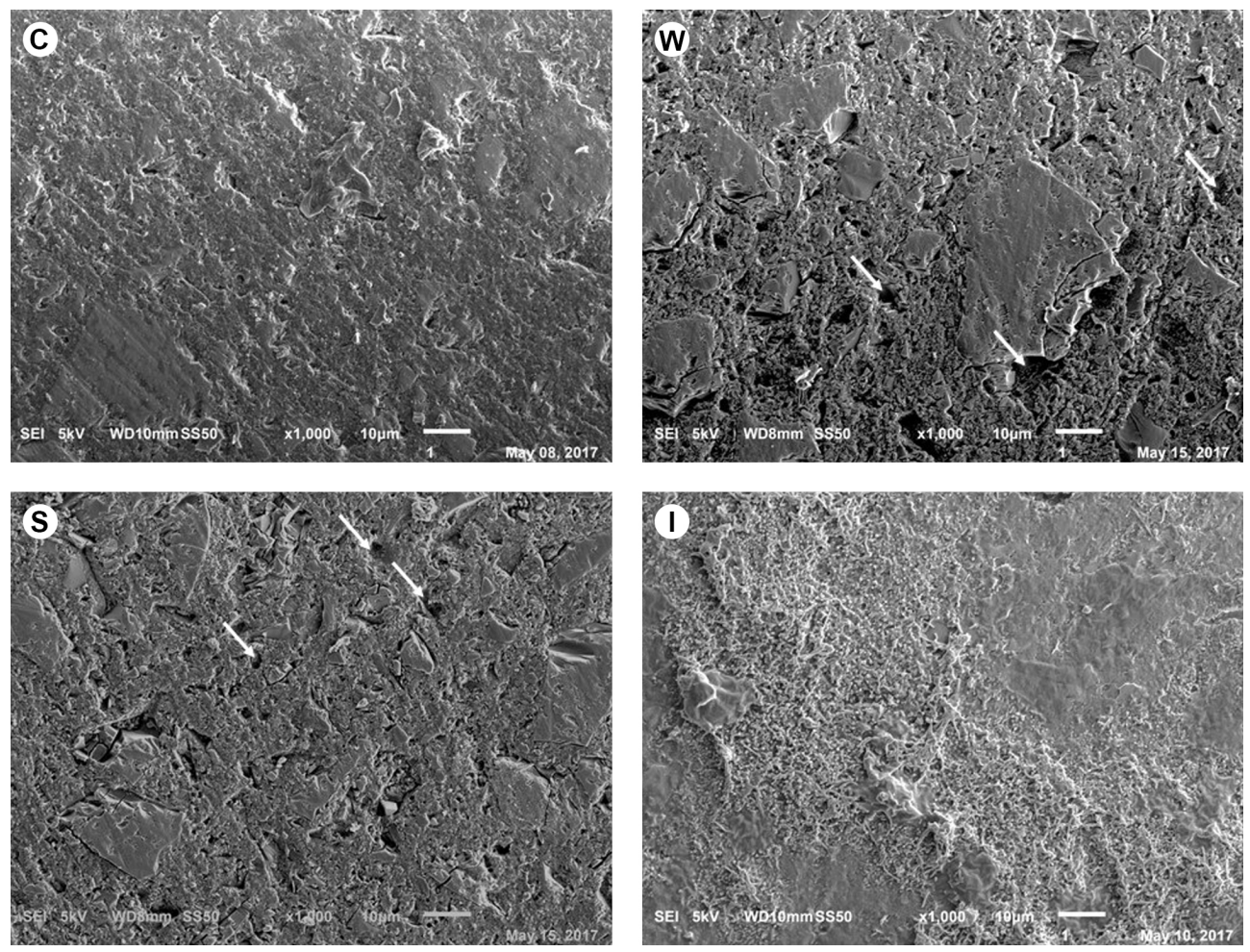

Figure 1. Scanning electron microscopy (1000×) images of Maxcem Elite samples after the following biodegradation methods: $24 \mathrm{~h}$ in distilled - the groups Wmc (B) and Smc (C), with a greater exposure of the filler particles compared to the control group Cmc (A). In the Imc (D) group, $\widetilde{\tau}$ the presence of a biofilm is noted, probably resulted from ineffectiveness in the removal of bacteria. The white arrows point to gaps and voids formed on the surface.
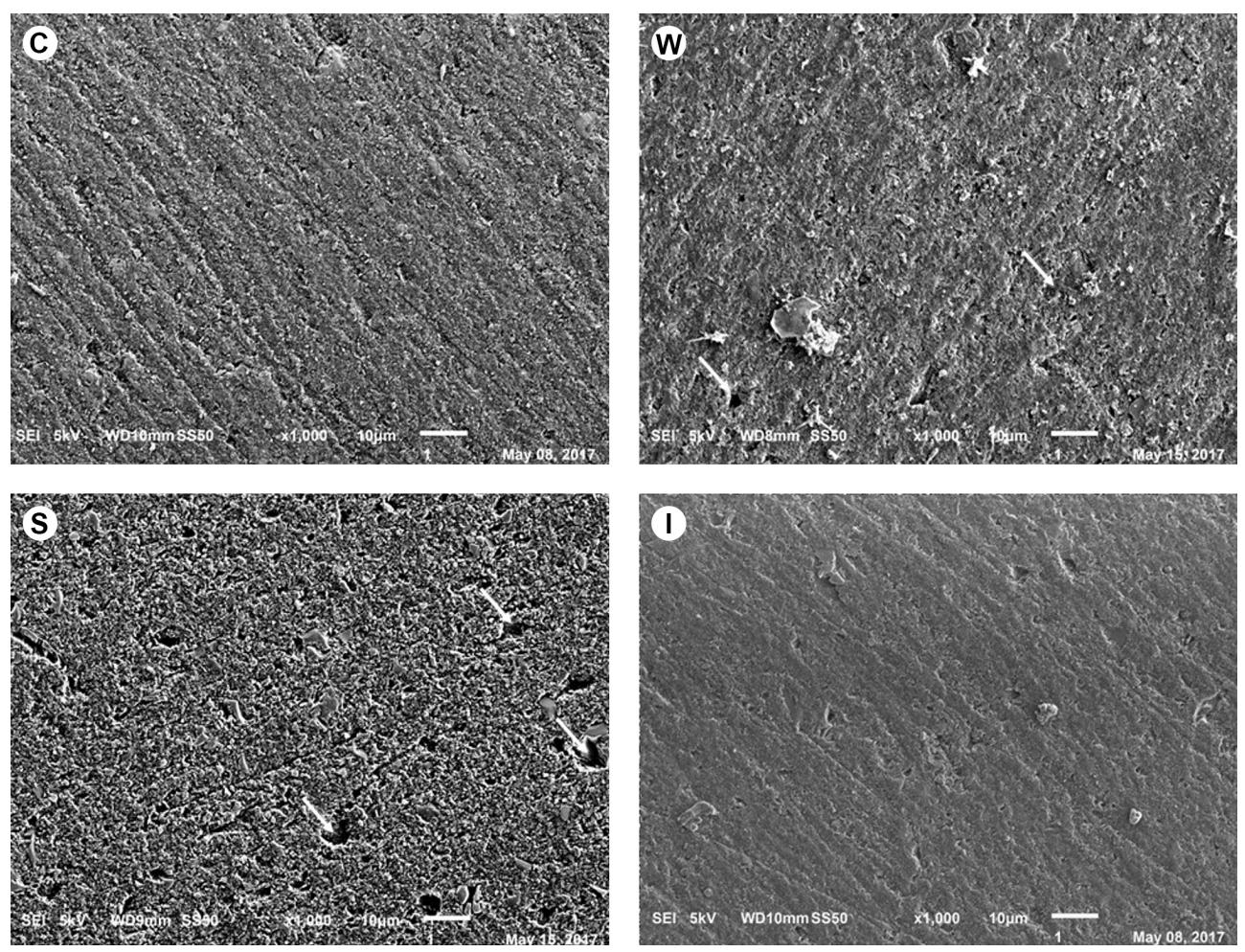

Figure 2. Scanning electron microscopy (1000×) images of Nexus NX3 samples after the following biodegradation methods: $24 \mathrm{~h}$ in distilled water (A), 7 days in distilled water (B), 7 days in saliva (C) and 7 days days in situ (D). There was little superficial change between groups, with greater surface irregularity in the $\mathrm{Snx}$ (C) group. The white arrows point to gaps and voids formed on the surface. 
market with the purpose of associating the optical quality of the ceramics and the modulus of elasticity closest to the inherent tooth of the resin compounds, thus determining a more aesthetic and less friable material $(16,18)$. However, some authors have shown that the weaker polymer-matrix can be easily separated from the ceramic-network, resulting in an increase of surface roughness (19). This was not found in this study, once the superficial roughness of VE was not significantly affected by the biodegradation methods. SEM images also showed similar patterns between the VE groups (Fig. 3). The fact that, in this study, the VE samples were not polished after machined may have contributed to the roughness maintenance, avoiding the phase separation experimented by other authors after polishing procedures (19). Future work, with evaluation by energy dispersive $\mathrm{x}$-ray spectroscopy can further elucidate this hypothesis.

Regardless of the fit of the prosthetic restoration, there is always exposure of the cement line to the oral environment, allowing for the biodegradation of the luting material (20). The softening of the organic matrix of the resin cements, a result of biodegradation, is potentiated by the mechanical action of tooth brushing, which increases the surface roughness of these materials and enhances the leaching of by-products (20). This effect may, in the long term, increase the risk for the development of secondary caries, periodontal disease, marginal discoloration and loss of retention of the restoration (10).

In this study, regardless of the biodegradation method, the Maxcem Elite group presented higher surface roughness when compared to Nexus NX and Vita Enamic. This fact was confirmed by the SEM images (Fig. 1), which demonstrated a greater surface irregularity of the Maxcem Elite cement samples in all the biodegradation methods. Considering that biofilm formation may be enhanced when the surface roughness exceeds $0.2 \mu \mathrm{m}$ (21), the surface performance of this material could be considered clinically critical.

The higher roughness presented by this material compared to the NX3 Nexus cement may be related to the filler size used in the composition of these materials (22). While the MC particles range from 2 to $4 \mu \mathrm{m}$, the NX has fillers of at most $0.6 \mu \mathrm{m}$ on average. Resin materials can be softened when under biodegradation, which enable the resin matrix to promote displacement of the filler particles (23). Thus, the displacement of larger particles, could lead to rougher surfaces.

The indirect restorative materials and luting agents subjected to an aqueous medium, such as saliva, are exposed to an biodegradation process that can determine the decrease of certain mechanical properties, such as surface microhardness (6). The diffusion of water to the interior of
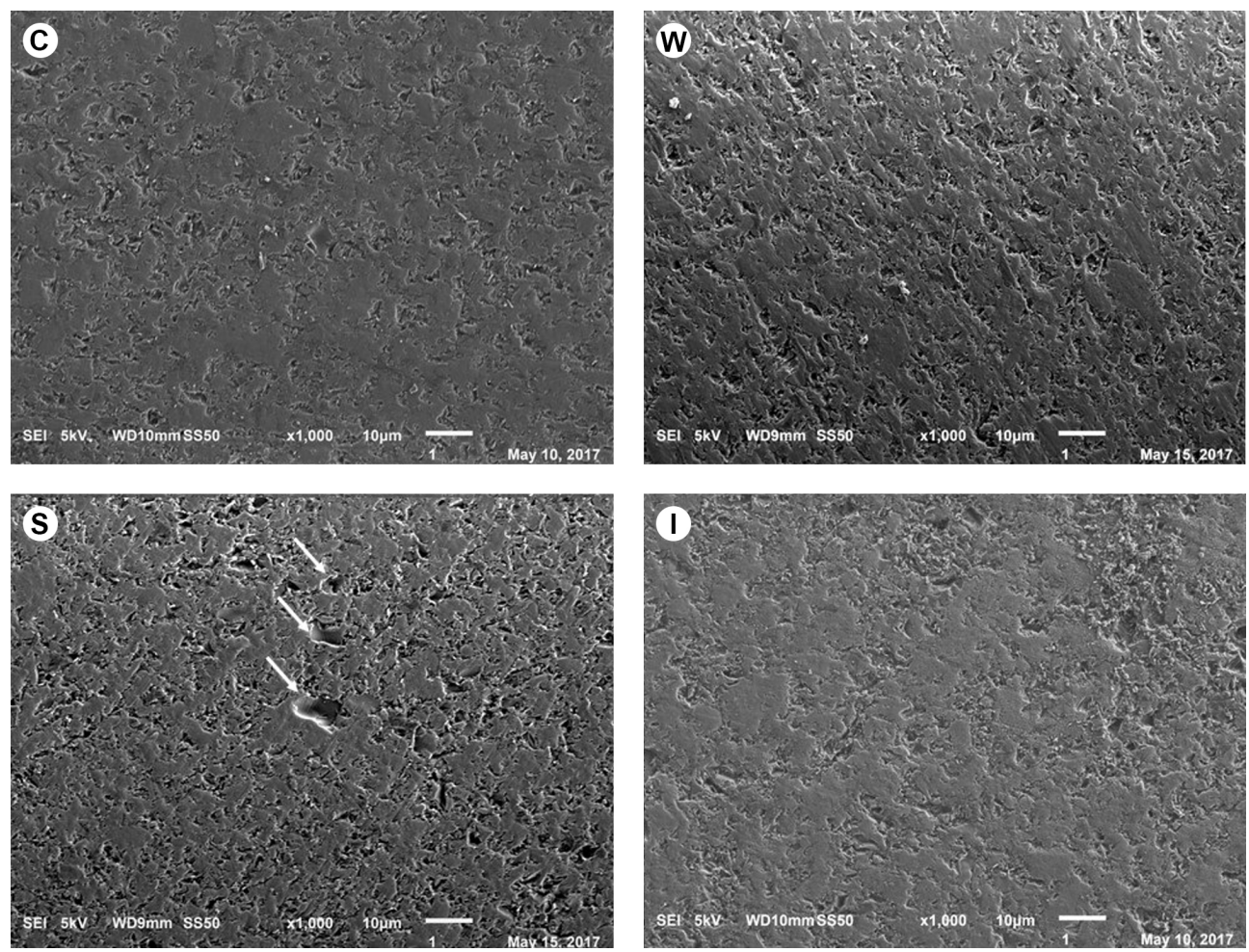

Figure 3. Scanning electron microscopy $(1000 \times)$ images of Vita Enamic samples after the following biodegradation methods: $24 \mathrm{~h}$ in distilled water (A), 7 days in distilled water (B), 7 days in saliva (C) and 7 days days in situ (D). There is little variation between groups, though there was a greater superficial irregularity in the Sve group (C). The white arrows point to gaps and voids formed on the surface. The white arrows point to gaps and voids formed on the surface. 
the material, potentiated by the chemical action of salivary enzymes, bacterial acids and/or from diet, can promote a decomposition of the superficial chemical bonds, thus weakening the material (7). Therefore, superficial hardness can be an important criterion to determine the material's resistance to biodegradation. Regardless of the material, saliva and in situ biodegradation promoted significant decrease in the VHN

The Vita Enamic group showed a significant decrease in surface microhardness for the Sve (234.9 VHN) and Ive (160.2 VHN) groups when compared to the Cve (321.9 VHN) and Wve (329.5 VHN) groups, rejecting the second hypothesis. Although dental ceramics are more inert, and therefore less influenced by the action of saliva and biofilm, it is suggested that the polymer component present in the hybrid ceramic system has a greater susceptibility to biodegradation when compared to conventional all-ceramic systems. The polymer network of Vita Enamic contains, according to the manufacturer, UDMA and TEGDMA (24), components which, when contacted with salivary enzymes, may undergo hydrolysis, and consequently cause softening of the resin portion of the material and subsequent diminish the surface microhardness.

On the other hand, the resin cements tested suffered less alteration of the VHN from the biodegradation methods. It is possible that the seven-day time period chosen for biodegradation in this study may have been insufficient to produce a significant change in the luting materials. This period was selected in order to simplify the in situ phase with the volunteers, reducing the probability of possible variables related to non-adherence to the protocol by the participants in long term studies. Padovani et al. (13), in a similar study, observed changes in surface roughness and microhardness of some direct restorative materials in seven days. In contrast, Bürgin et al. (25), in a study evaluating the biodegradation of four resin cements through different storage sites, found that the storage time of 16 days was insufficient to promote detectable biodegradation of the materials tested. Further studies with different time frames must be performed to verify the biodegradation resistance of materials through time.

Though this was a short-term study, the in situ model assessed here may provide promising results regarding the clinical performance of the materials tested. As observed in this study, even though the hybrid ceramic tested contained a considerable ceramic content on is composition, it did not exclude the material from suffering biodegradation of its surface, demonstrating the deleterious effect of oral bacteria in restorative material with resin matrix. The deterioration of indirect materials interferes in the clinicians choice during the rehabilitation treatment, once the materials performance is directly related to the restoration longevity. Considering the importance of the biodegradation resistance to the success of indirect restorative materials, more studies, with different time frames, must be performed in order to establish the behavior of materials in the oral environment in long term.

Within the limitations and objectives of this study, it was observed that regardless of the material, the in situ biodegradation method promoted the greatest alteration on the Ra. Regarding the materials, the superficial hardness of the hybrid ceramic tested was negatively affected by the biodegradation methods and, among the resin cements evaluated, the Nexus NX3 presented better performance. Therefore, it was concluded that both hybrid ceramic and resin cement suffered in vitro and situ biodegradation.

\section{Resumo}

0 objetivo deste trabalho foi avaliar os efeitos da biodegradação in vitro e in situ nas caracteristicas superficiais de dois cimentos resinosos e de um sistema cerâmico hibrido. Cento e oitenta espécimes $(4 X 1,5 \mathrm{~mm})$ de cada material (Maxcem Elite, NX3 Nexus e Vita Enamic) foram distribuidos aleatoriamente em doze grupos $(n=15)$ de acordo com o material e o método de biodegradação. Os espécimes foram então submetidos aos seguintes desafios: armazenamento em água destilada $37^{\circ} \mathrm{C}$ por 24 horas ou 7 dias, armazenamento por 7 dias, a $37^{\circ} \mathrm{C}$, em saliva estimulada ou in situ. 0 estágio in situ correspondeu à preparação de 15 dispositivos intra-orais palatinos, utilizados por 7 dias. Cada dispositivo apresentou 3 nichos, onde uma amostra de cada material foi acomodada. As amostras dos grupos saliva e in situ sofreram um desafio cariogênico, correspondendo à aplicação de uma solução de $20 \%$ de sacarose, 10 vezes ao longo de cada dia. Após cada método de biodegradação, foram realizadas as análises de rugosidade superficial (Ra), dureza Vickers (VHN) e microscopia eletrônica de varredura (MEV). Os dados coletados foram analisados por meio do teste de Levene, ANOVA two-way e teste de Tukey $(\alpha=5 \%)$. 0 desafio in situ promoveu maior degradação, independentemente do material. Em relação aos materiais, a VHN do Vita Enamic foi afetada negativamente por todos os métodos de degradação e o Nexus NX3 apresentou melhor desempenho que o cimento autoadesivo testado. Portanto, dentro das condições deste trabalho, concluiu-se que a biodegradação in situ pode afetar negativamente as caracteristicas superficiais de materiais restauradores indiretos.

\section{Acknowledgements}

This work was supported by the Brazilian Federal Agency for Support and Evaluation of Graduate Education - CAPES and funded with public resources obtained through the "Public Call 15/2017" - Fundação Araucária/Secretaria de Estado da Ciência, Tecnologia e Ensino Superior do Paraná (SETI), grant \# 15.561.047-6.

\section{References}

1. Barbosa RP, Pereira-Cenci T, Silva WM, Coelho-De-Souza FH, Demarco FF, Cenci MS. Effect of cariogenic biofilm challenge on the surface hardness of direct restorative materials in situ. J Dent 2012;40:359363.

2. Brentel AS, Kantorski KZ, Valandro LF, Fúcio SB, Puppin-Rontani RM, Bottino MA. Confocal laser microscopic analysis of biofilm on newer feldspar ceramic. Oper Dent 2011;36:43-51.

3. Glauser S, Astasov-Frauenhoffer M, M€Uleer Ja, Fischer J, Waltimo T, Rohr N. Bacterial colonization of resin composite cements: influence of material composition and surface roughness. Eur J Oral Sci 2017;125:294-302.

4. Şen N, Tuncelli B, Göller G. Surface deterioration of monolithic CAD/ 
CAM restorative materials after artificial abrasive toothbrushing. J Adv Prosthodont 2018;10:271-278.

5. Zero DT. In situ caries models. Adv Dent Res 1995;9:214-230.

6. Nedeljkovic I, De Munck J, Ungureanu AA, Slomka V, Bartic C, Vananroye $A$, et al. Biofilm-induced changes to composite surface. J Dent 2017; 63:36-43.

7. Blumer L, Schmidli F, Weiger R, Fischer J. A systematic approach to standardize artificial aging of resin composite cements. Dent Mater 2015;31:855-863.

8. Nedeljkovic I, De Munck J, Ungureanu AA, Slomka V, Bartic C, Vananroye $A$, et al. Biofilm-induced changes to the composite surface. J Dent 2017;63:36-43.

9. Khvostenko D, Hilton TJ, Ferracane JL, Mitchell JC, Kruzic JJ. Bioactive glass fillers reduce bacterial penetration into marginal gaps for composite restorations. Dent Mater 2016;32:73-81.

10. Reis A, Martins GC, De Paula EA, Sanchez AD, Loguercio AD. Alternative aging solutions to accelerate resin-dentin bond degradation. J Adhes Dent 2015;17:321-328.

11. de Paula AB, Fúcio SBP, Ambrosano GM, Alonso RCB, Sardi JCO, PuppinRontani RM. Biodegradation and abrasive wear of nano restorative materials. Oper Dent 2015;36:670-677.

12. Kim KH, Loch C, Waddell JN, Tompkins G, Schwass D. Surface characteristics and biofilm development on selected dental ceramic materials. Int J of Dent 2017;2017:7627945.

13. Padovani GC, Fucio SBP, Ambrosano GMB, Sinhoreti MAC, PuppinRontani RM. In situ surface biodegradation of restorative materials. Oper Dent 2014;39:349-360.

14. Esteban Florez FL, Hiers RD, Smart K, Kreth J, Qi F, Merritt J, et al. Realtime assessment of Streptococcus mutans biofilm metabolism on resin composite. Dent Mater 2016;32:1263-1269.

15. Astasov-Frauenhoffer M, Glauser S, Fischer J, Schmidli F, Waltimo T, Rohr N. Biofilm formation on restorative materials and resin composite cements. Dent Mater 2018;34:1702-1709.

16. Goujat A, Abouelleil $H$, Colon $P$, Jeannin C, Pradelle N, Seux D, et al. Mechanical properties and internal fit of 4 CAD-CAM block materials.
J Prosthet Dent 2018;119:384-389.

17. Zhu L, Li Y, Carrera CA, Chen YC, Li M, Fok A. Calibration of a lacticacid model for simulating biofilm-induced degradation of the dentincomposite interface. Dent Mater 2017;33:1315-1323.

18. Della Bona AD, Corazza PH, Zhang Y. Characterization of a polymerinfiltrated ceramic-network material. Dent Mater 2015;30:564-569.

19. Awad D, Stawarczyk B, Liebermann A, Ilie N. Translucency of esthetic dental restorative CAD/CAM materials and composite resins with respect to thickness and surface roughness. J Prosthet Dent 2015; 113:534-540.

20. Furuichi T, Takamizawa T, Tsujimoto A, Miyazaki M, Barmeier WW, Latta A. Mechanical properties and sliding-impact wear resistance of selfadhesive resin cements. Oper Dent 2016;41:83-92.

21. Bollen CM, Lambrechts $P$, Quirynen M. Comparison of surface roughness of oral hard materials to the threshold surface roughness for bacterial plaque retention: a review of the literature. Dent Mater 1997;13:258-269.

22. Ruivo MA, Pacheco RR, Sebold M, Giannini M. Surface roughness and filler particles characterization of resin-based composites. Microsc Res Tech 2019;82:1756-1767.

23. Hyun HK, Salehi S, Ferracane JL. Biofilm formation affects surface properties of novel bioactive glass-containing composites. Dent Mater 2015;31:1599-1608.

24. Koizumi H, Saiki O, Nogawa $H$, Hiraba $H$, Okazaki T; Matsumura H. Surface roughness and gloss of current CAD/CAM resin composites before and after toothbrush abrasion. Dent Mater J 2015;34:881-887.

25. Bürgin S, Rohr N, Fischer J. Assessing degradation of composite resin cements during artificial aging by Martens hardness. Head Face Med 2017;13:9

Received November 18, 2019 Accepted January 14, 2020 